\title{
Impact of Job Skills Training Programs on Urban Poverty
}

\author{
Manajemen Sumber Daya Manusia
}

\author{
Suparmono \\ Sekolah Tinggi Ilmu Manajemen YKPN Yogyakarta, Indonesia. \\ Email: suparmono@stimykpn.ac.id
}

\begin{abstract}
The aim of this study is to examine the effect of the ready-to-work skills training offered by the Republic of Indonesia's Ministry of Social Affairs on urban poor people who are members of micro and small businesses to mitigate urban poverty. This research was conducted in Balikpapan City during the 2019 season. The empirical approach used is statistics that are descriptive. Data collection was performed by telephone interviews with job skills training program recipients. As a result, in the form of growing skills, the training programs offered to the urban poor and some micro and small enterprises had a positive effect and those who did not pursue their business were able to find work due to the training they got. The flaw of this preparation is linked to the training recipients' continuous level of ability such that they are not yet at the advanced level.
\end{abstract}

\section{Keyword: Job Skills Training, Urban Poverty, Entrepreneurship, Unemployment}

\section{Introduction}

Reducing poverty has been a central focus for social science scholars, from economics to banking, management and entrepreneurship (Si et al., 2020). Poverty is a challenge for almost every country in the world, particularly in developing countries. Poverty has a multidimensional aspect, meaning there are multiple needs for humans. Poverty can therefore be seen mainly because of properties, experience, skills and secondary aspects, such as being poor, namely in the form of poor social networks, financial resources and information (Wijaya, Istiqomah and Arintoko, 2020).

Although entrepreneurship is receiving rising attention in developing economies at the base of the Pyr-amid, scholars have devoted less effort to exploring entrepreneurship as a solution to poverty in advanced economies. Yet, in most advanced economies, poverty rates have not changed significantly in 50 years and the income gap between rich and poor continues to widen (Morris, Santos and Neumeyer, 2020).

Owing to the high prices of urban needs and low competition and social tolerance, the urban poor face heterogeneous issues, so that the magnitude of urban poverty is greater than in rural areas (Silva-Laya et al., 2020). 
A significant portion of program costs are typically compensated for by the intangible (training and mentorship) component. Skeptics may argue that development practice has a long history of misallocating resources paternalistically (Sedlmayr, Shah and Sulaiman, 2020). Why engage in training and mentorship on behalf of participants? Why not by extending the monetary transfer component of the program and encouraging them to invest in themselves, give the beneficiaries expanded agency over program resources? If integrated micro-enterprise growth is indeed a more cost-effective alternative than unconditional poverty-reduction cash transfers, this may have major policy consequences (Li, Shi and Xue, 2020).

Executive processes such as focus, inhibitory control, working memory, cognitive flexibility, and planning can be characterized as a complex collection of skills, such as those involved in learning environments, involved in the management of feelings, thoughts, and behaviors during objective action (Giovannetti et al., 2020).

The aim of this study was to examine the effect of government training given to the poor who are members of micro and small enterprises through the Manpower Office to reduce urban poverty. Literature has shown that poverty, particularly when financial markets are not well established, can have a negative effect on investment and GDP growth. (Breunig and Majeed, 2020). It can also be seen that poverty can have an effect on the whole of the economy. The point is that poverty must be resolved urgently by the government to make growth more equal and faster (Mahembe and Odhiambo, 2019).

The Balikpapan City Government through the Manpower Office routinely carries out workforce training for poor families. This is done to increase the skills and competencies of the community so that later they can be absorbed in the world of work and increase income. The budget for implementing this training has increased every year, where in 2017 the budget was IDR 331,000,000. Until 2020, this training budget will increase to IDR 382,989,000. The increase also occurred in budget realization, where in 2017 the realization was IDR 217,580,000. Until 2019, the realization increased to Rp. 360,320,000.

\section{Literature Review}

There are causes that cause a person or a family to be poor, one of which is the low level of education, while the quality of the human resources of a person is understood to be seen from the level of education, lower education represents the low quality of human resources and can contribute to poor people. The greater the education of an individual, the greater 
the likelihood of a better life, the greater the quality of having a job. (Isnaini, Ahmad and Suharno, 2020).

Entrepreneurship has been recognized as an important part of economic growth. This is true for developing countries, such as Indonesia, in particular (Meyer and Hamilton, 2020). Poverty exists because, because of limited skills, people do not access employment or open businesses, so people need training and education (Huang et al., 2020). Poverty is a disorder that happens because people come from poor backgrounds as well, but children also encounter poverty at an early age. (Chaudry and Wimer, 2016). Children need to get the education and skills required to enter the world of good work and be able to become effective entrepreneurs in order to escape poverty ( $\mathrm{Li}$, Shi and Xue, 2020).

Sustainable Development Goals (SDG's) carry five fundamental principles that balance the economic, social and environmental dimensions, namely 1) People (humans), 2) Planet (earth), 3) Prosperty (prosperity), 4) Peace (peace), and 5) Partnership (cooperation). The SDGs agreement has 17 goals and 169 targets, in contrast to the MDGs which only have 8 goals and 21 targets. The MDGs program has weaknesses because the preparation and implementation are exclusive and very bureaucratic without involving the role of non-government stakeholders, such as civil society organizations, universities / academics, the business and private sectors, and other groups.

\section{Methods}

The training is divided into 3 themes, namely training in sewing, catering, and automotive mechanics with 16 participants for each training theme. The training participants were dominated by 32 women because sewing and culinary were intended only for women, especially housewives from the Family Hope Program (PKH). Judging by the level of education of the training participants, most of them are SMK graduates, as many as 16 people. Meanwhile, there are 11 high school students. The rest are SD and SMP graduates with 10 each.

The data collection method was carried out by conducting telephone interviews and sending questionnaires via google form to the poor who received training programs provided by the Balikpapan City Manpower Office. After data from interviews and questionnaires, data analysis was performed using descriptive statistical analysis. The results of descriptive statistical analysis are depicted in a pie chart to make it easier to interpret the data.

\section{Finding and Result}

Based on the results of processed data, in 2017 the total budget for poverty reduction was IDR $6,867,401,000$ with a realization of IDR $1,851,026,150$. With such a large budget realization, the 
average performance achievement was $110.42 \%$ and the average budget achievement was $162.41 \%$. Then in 2018, the total budget for poverty alleviation programs was IDR 7,976,188,000 with a budget realization of IDR 2,419,229,950. The realization of this budget increased by Rp.568,203,800. Meanwhile, the average achievement of the realization of the performance increased to $370.78 \%$ and the average achievement of the realization of the budget also increased to $175.22 \%$. In 2019 , the poverty reduction program budget has again increased to IDR 12,576,312,000 with a realization of $10,796,734,730$. there was an increase in the realization of. The significant increase in realization was because the budget for the health insurance program for the poor was absorbed as much as Rp6,570,858,216. Continuing in 2020, the poverty reduction program budget has decreased to Rp10,817,688,000 with the realization of Rp3,510,273,665 until the second quarter.

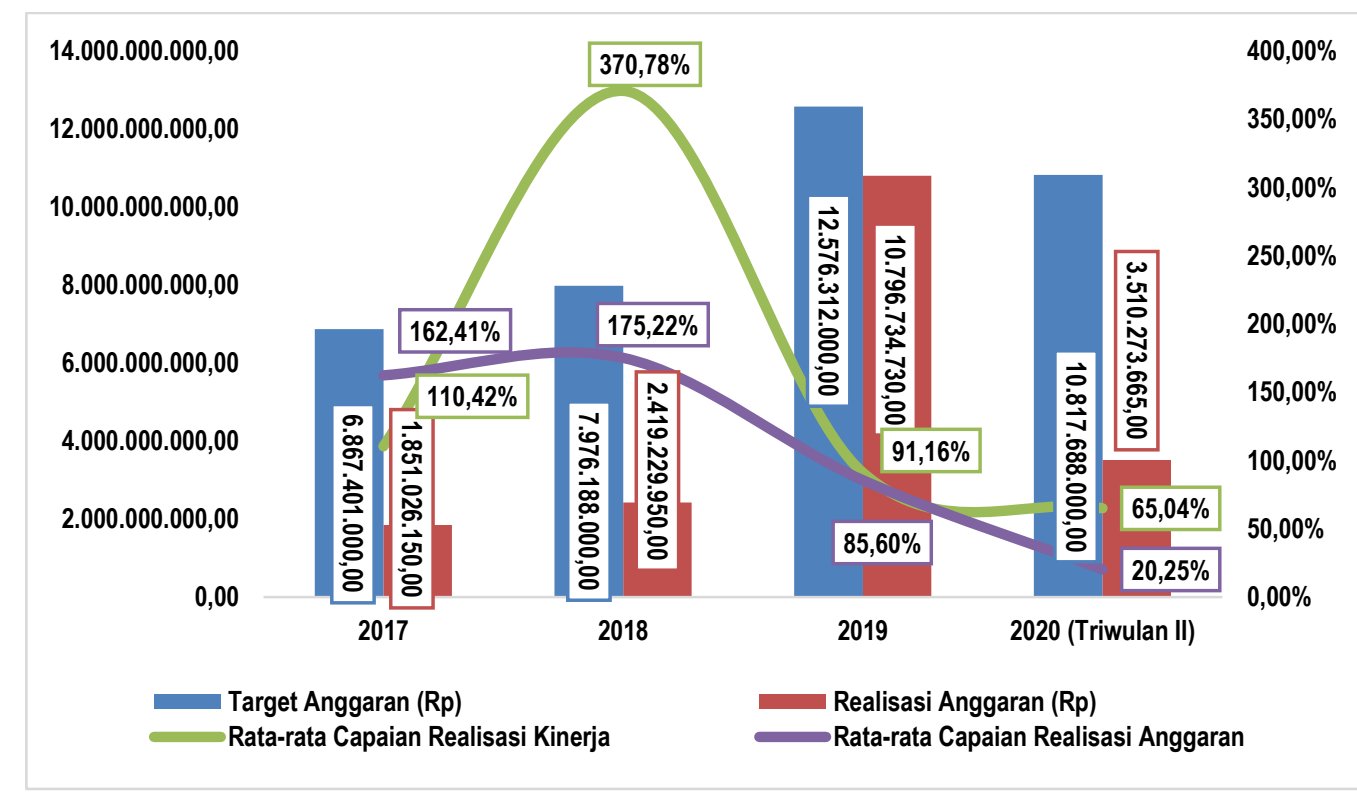

Figure 1. Targets, Realizations, and Achievements of Poverty Reduction Programs in the City of Balikpapan in 2017-2020

Source: Information System for Development Control and Evaluation, Bappeda Balikpapan City

Based on the training theme, $37 \%$ attended sewing training and $11 \%$ culinary training. Sewing training consists of three stages, namely basic, skilled, and proficient. This is what causes the frequency of training to be higher than that of culinary. Meanwhile, for electronic goods training, 44\% attended refrigeration engineering training and 7 participated in automotive mechanics. The high percentage of participants participating in refrigeration engineering training is due to the increasing need for the world of work to absorb competent workers in refrigeration electronics such as air conditioners, refrigerators, vehicle air conditioners, and others. 


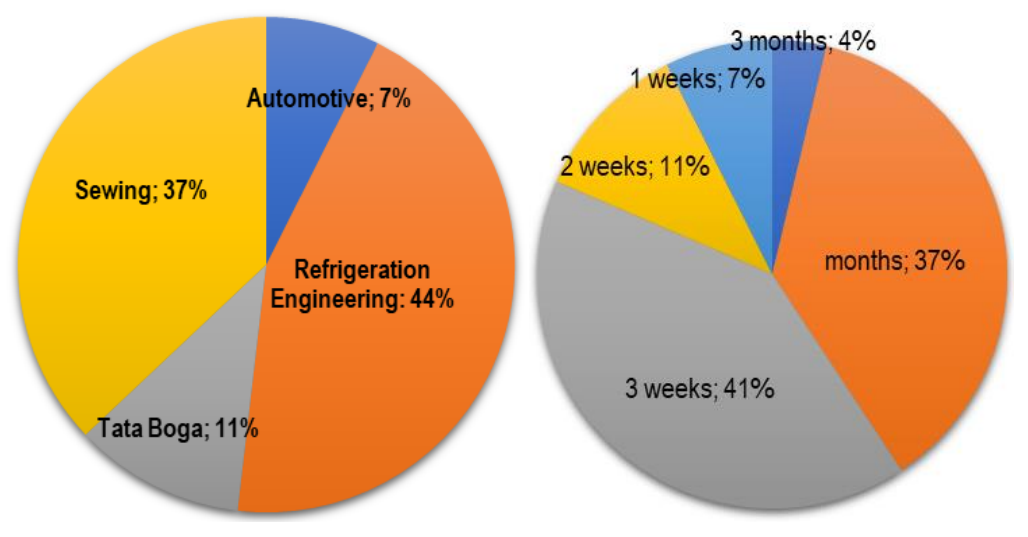

Figure 2. Training Diagram

The advantages of conducting the training were most often expressed in ways of teaching trainers/mentors that were easy to understand, as many as $44.44 \%$ of participants expressed this. The easy way to understand the material being taught made the participants directly able to apply the knowledge they got, as many as $40.74 \%$ of participants said this was an advantage of the training. In addition, the absence of registration fees and bonuses for participants who were able to participate in the training properly were also advantages that were expressed by $3.70 \%$ each. However, there were still participants who thought that there was no advantage in the implementation of the training, this was revealed by $7.41 \%$ of training participants.

As for the weaknesses of the participants, most of them still had material that was not fully understood, as many as $18.52 \%$ of participants expressed this. Then other weaknesses, namely the training time is not long enough, not yet accommodating all types of training, inadequate equipment, not given tools for practice after completion of training and the provision of unfair transport fees were each mentioned by $3.7 \%$ of the participants. However, $62.96 \%$ of training participants stated that there were no weaknesses in the training process.

The strengths of the training that were mostly expressed were the easy to understand way of teaching trainers/mentors, as many as $44.44 \%$ of participants expressed this. The easy way to understand the material being taught made the participants directly able to apply the knowledge they got, as many as $40.74 \%$ of participants said this was an advantage of the training. In addition, the absence of registration fees and bonuses for participants who were able to participate in the training properly were also advantages that were expressed by $3.70 \%$ each. However, there were still participants who thought that there was no advantage 
in the implementation of the training, this was revealed by $7.41 \%$ of training participants.

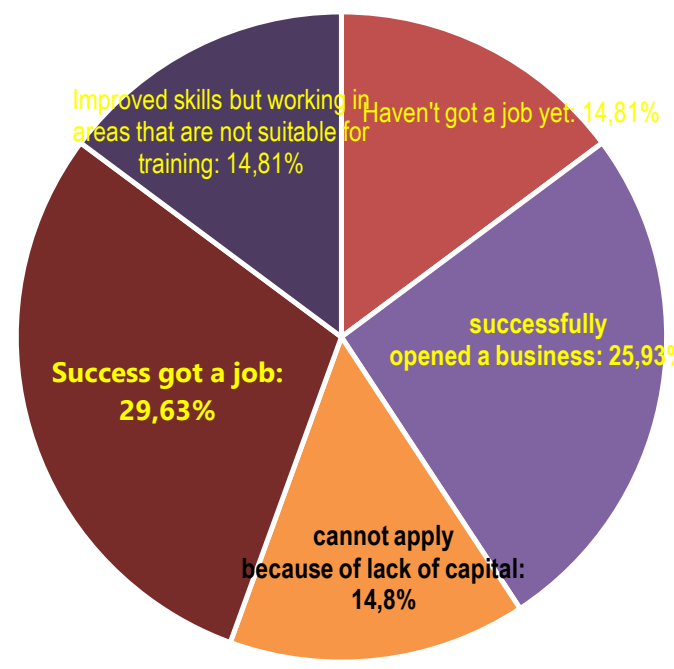

Figure 3. Training Diagram

\section{The Results of Training on The Job}

As many as $29.63 \%$ of training participants said that after the training they could immediately get a job. Then as many as $25.93 \%$ said they could open their own business. Based on the two most common answers, those who stated that they immediately got a job came from the theme of training in automotive mechanics and refrigeration engineering, while those who opened their own business came from the theme of training in catering and sewing. As many as $14.81 \%$ of the training participants have worked but it is different from the training field that was followed. Meanwhile, as many as $14.81 \%$ of training participants from the theme of sewing revealed that they could apply the knowledge they learned, but were limited to the facilities / means to practice it. The remaining $14.81 \%$ of training participants still did not find a job and were looking for work.

\section{Conclusion}

The training program provided to micro and small entrepreneurs has a positive impact in the form of increasing skills and those who do not continue their business can get jobs according to the training they receive. The weakness in this training is related to the continuing skill level of the training recipients so that they are not yet at the advanced level.

Training participants said that after the training they could immediately get a job and open their own business. Training participa immediately got a job came from the theme of 
training in automotive mechanics and refrigeration engineering, while those who opened their own business came from the theme of training in catering and sewing. The training participants have worked but it is different from the training field that was followed. Meanwhile, as many as $14.81 \%$ of training participants from the theme of sewing revealed that they could apply the knowledge they learned, but were limited to the facilities / means to practice it. The remaining $14.81 \%$ of training participants still did not find a job and were looking for work.

\section{Acknowledgement}

The results of this study are a collaboration between the Balikpapan City Government through the Regional Development Planning Agency and Development Research together with Sinergi Visi Utama Consulting Yogyakarta. For this reason, the author as an expert would like to thank both parties. In addition, the authors would like to thank Sekolah Tinggi Ilmu Manajemen YKPN Yogyakarta for collaborating and funding assistance in this research.

\section{Limitations}

The limitations of this study are related to the respondents involved in this study. Respondents' ability to answer questions in this study is still limited because the data collection method is through google forms and telephone, so that there may be bias in their ability to answer. Respondents who attended this training were spread out from their previous addresses and some changed their cell phone numbers. For further research, it is best if the interviews are conducted directly so that they can reveal the problems and impacts of the training in more depth.

\section{Refferences}

Amalia, M. R. (2018). Analisis Pengaruh Pelatihan, Bantuan Modal, dan Cara Pengelolaan Usaha Terhadap Pendapatan Usaha Mikro Kecil dan Menengah . Permana : Jurnal Perpajakan, Manajemen, Dan Akuntansi, 10(2), 248-256. https://doi.org/10.24905/permana.v10i2.85

Breunig, R. and Majeed, O. (2020) 'Inequality, poverty and economic growth', International Economics. CEPII (Centre d'Etudes Prospectives et d'Informations Internationales), a center for research and expertise on the world economy, 161, pp. 83-99. doi: 10.1016/j.inteco.2019.11.005.

Chaudry, A. and Wimer, C. (2016) 'Poverty is Not Just an Indicator: The Relationship between Income, Poverty, and Child Well-Being', Academic Pediatrics. Elsevier Inc, 16(3), pp. S23-S29. doi: 10.1016/j.acap.2015.12.010.

Giovannetti, F. et al. (2020) 'Impact of an individualized cognitive training intervention in 
preschoolers from poor homes', International Journal of Environmental Research and Public Health, 17(8). doi: 10.3390/ijerph17082912.

Huang, F. et al. (2020) 'Of job, skills, and values: Exploring rural household energy use and solar photovoltaics in poverty alleviation areas in China', Energy Research and Social Science. Elsevier, 67(March), p. 101517. doi: 10.1016/j.erss.2020.101517.

Isnaini, F. N., Ahmad, A. A. and Suharno, S. (2020) 'Determinan dan Trend Kemiskinan di Kabupaten Wonosobo Provinsi Jawa Tengah', Ekonomis: Journal of Economics and Business, 4(1), p. 120. doi: 10.33087/ekonomis.v4i1.121.

Li, J., Shi, Z. and Xue, E. (2020) 'The problems, needs and strategies of rural teacher development at deep poverty areas in China: Rural schooling stakeholder perspectives', International Journal of Educational Research. Elsevier, 99(March 2019), p. 101496. doi: 10.1016/j.ijer.2019.101496.

Mahembe, E. and Odhiambo, N. M. (2019) 'Foreign aid and poverty reduction: A review of international literature', Cogent Social Sciences. Cogent, 5(1). doi: 10.1080/23311886.2019.1625741.

Meyer, N. and Hamilton, L. (2020) 'Female entrepreneurs' business training and its effect on various entrepreneurial factors: Evidence from a developing country', International Journal of Economics and Finance Studies, 12(1), pp. 135-151. doi: 10.34109/ijefs.202012109.

Morris, M. H., Santos, S. C. and Neumeyer, X. (2020) 'Entrepreneurship as a solution to poverty in developed economies', Business Horizons. Elsevier Ltd, 63(3), pp. 377-390. doi: 10.1016/j.bushor.2020.01.010.

Risnawati, H., \& Retnoningsih, S. (2020). Pengaruh Pemberian Insentif, Pelatihan Kerja dan Pengendalian Intern terhadap Efektivitas Kinerja Karyawan. Permana : Jurnal Perpajakan, Manajemen, Dan Akuntansi, 12(2), 137-152. https://doi.org/10.24905/permana.v12i2.99

Sedlmayr, R., Shah, A. and Sulaiman, M. (2020) 'Cash-plus: Poverty impacts of alternative transfer-based approaches', Journal of Development Economics. Elsevier B.V., 144, p. 102418. doi: 10.1016/j.jdeveco.2019.102418.

Si, S. et al. (2020) 'Business, Entrepreneurship and Innovation Toward Poverty Reduction', Entrepreneurship and Regional Development. Routledge, 32(1-2), pp. 1-20. doi: 10.1080/08985626.2019.1640485.

Silva-Laya, M. et al. (2020) 'Urban poverty and education. A systematic literature review', Educational Research Review. Elsevier, 29(April), p. 100280. doi: 10.1016/j.edurev.2019.05.002.

Wijaya, H., Istiqomah, I. and Arintoko, A. (2020) 'Analisis Faktor - Faktor yang Mempengaruhi Kemiskinan (Studi Kasus di Kabupaten Banjarnegara, Cilacap, Purbalingga, Kebumen, dan Banyumas)', Jurnal Ilmiah Universitas Batanghari Jambi, 20(2), p. 451. doi: 10.33087/jiubj.v20i2.954. 